\title{
Habitat associations and dispersal of black sea bass from a mid-Atlantic Bight reef
}

\author{
Mary C. Fabrizio $^{1, *}$, John P. Manderson ${ }^{2}$, Jeffrey P. Pessutti ${ }^{2}$ \\ ${ }^{1}$ Virginia Institute of Marine Science, College of William \& Mary, PO Box 1346, Gloucester Point, Virginia 23062, USA \\ ${ }^{2}$ National Marine Fisheries Service, Northeast Fisheries Science Center, James J. Howard Marine Sciences Laboratory, \\ 74 Magruder Road, Highlands, New Jersey 07732, USA
}

\begin{abstract}
We examined habitat associations of 122 adult black sea bass Centropristis striata at a temperate reef off the coast of New Jersey, USA. The study site, located within the Historic Area Remediation Site, encompassed $46.1 \mathrm{~km}^{2}$ and included areas of rocky bottom and highly variable bathymetry. Factors influencing dispersal and habitat use were determined from acoustic telemetry data collected between May and December 2003 from a grid of 72 moored receivers. About 2.7 times as many black sea bass used the site in summer as in fall. Fish were associated with relatively shallow, complex habitats characterized by previously placed, coarse-grain material that may have provided food, shelter, or both. Deep areas $(>27.5 \mathrm{~m})$ with coarse-grain material were rarely used. Dispersal of black sea bass was not a pulse event, but rather a steady movement of individuals away from the site as inshore bottom water temperatures declined between late September and mid-December. Both temperature and photoperiod may serve as cues to the initiation of offshore movements of fish to wintering grounds near the edge of the shelf. Some black sea bass resided at the reef for periods of up to 6 mo encompassing the spawning period; as such, these habitats may be important to the continued production of the stock. In the mid-Atlantic Bight, surveys to estimate the relative abundance of this species during their inshore residency period should be conducted in July-August in structurally complex habitats and in waters $<28 \mathrm{~m}$ deep.
\end{abstract}

KEY WORDS: Black sea bass - Acoustic telemetry - Dispersal - Fish habitat - Movement . Continental shelf $\cdot$ Negative binomial model

Resale or republication not permitted without written consent of the publisher

\section{INTRODUCTION}

Understanding dynamic habitat use by fishes requires an approach that allows information to be gathered from individual fishes over appropriate spatial $(<1 \mathrm{~km})$ and temporal (e.g. several seasons) scales (Manderson et al. 2011). On broad spatial scales, such as the US continental shelf, fish habitat use can be deduced from fishery-independent surveys that gauge changes in density over time and provide a snapshot of the distribution of fish over a relatively large area. For example, bottom trawl surveys can provide coarse-scale (1 to $1000 \mathrm{~km}$ ) indications of the distribution of demersal fishes, but such surveys are spatially biased, reflecting density only in areas accessible to the sampling gear. Even when combined with data on seafloor habitat characteristics, habitat associations of fish may remain elusive (Lathrop et al. 2006). In addition, associations of fish with habitat features that occur at scales smaller than the area swept by the trawl cannot be discerned (Malatesta \& Auster 1999). Acoustic telemetry studies have been used increasingly to address ecological questions concerning habitat use (e.g. Wearmouth \& Sims 2009, Hammerschlag-Peyer \& Layman 2010, Knip et al. 2012), as well as residency of animals at specific habitats (e.g. Douglas et al. 2009). However, large-scale acoustic studies on the continental shelf are relatively uncommon. 
In the present study, we used acoustic telemetry to investigate the habitat affinity of black sea bass Centropristis striata, an important temperate reef species, at a site in the mid-Atlantic Bight known to support a diverse and abundant fish fauna targeted by recreational fishers. Black sea bass, a demersal species in the family Serranidae, are found along the Atlantic coast from Massachusetts to Florida, USA, and in the Gulf of Mexico (Collette \& Klein-MacPhee 2002). Three stocks are currently recognized: Gulf of Mexico, south Atlantic Bight, and mid-Atlantic Bight (Roy et al. 2012); the latter is the focus of this study. Like other temperate reef fishes, black sea bass are typically associated with hard bottom structures such as reefs and rock outcroppings. In the mid-Atlantic Bight, areas that contain some hard bottom and that are characterized by structural complexity have been termed 'reefs'; some of these areas include anthropogenic structures, but are nonetheless used by species typically associated with temperate reefs (Steimle \& Zetlin 2000).

Adult black sea bass in this region undertake annual migrations across the continental shelf: individuals spend the winter offshore in the middle- to outer-continental shelf and migrate inshore in the spring as water temperatures increase (Musick \& Mercer 1977, Moser \& Shepherd 2009). Black sea bass spawn in nearshore waters from April to October at depths between 18 and $45 \mathrm{~m}$ (Musick \& Mercer 1977). In the fall, as inshore waters begin to cool, adult and young-of-the-year black sea bass migrate offshore to the continental shelf. Like many other Serranidae, black sea bass are protogynous hermaphrodites. Mature males exhibit a bright blue hump on the nape during the spawning season; however, differentiation of females from smaller mature males is not possible by external morphological characters alone (NEFSC 2012). Rates of sex change, growth, and mortality are associated with fish size (Shepherd \& Idoine 1993); smaller fish tend to be female, and as such, females also experience lower fishing mortality rates. The mid-Atlantic Bight stock is subject to recreational and commercial harvesting, with fisheries targeting individuals associated with reefs and other hard-bottom structure in coastal waters (Shepherd \& Terceiro 1994).

Although black sea bass are known to use midAtlantic Bight reefs, the length of time individual fish remain at a particular reef during their inshore summer residency and the affinity of black sea bass for various habitat types present at a particular reef site are unknown. Because many fish species exhibit diel and seasonal changes in habitat use (Cote et al.
2003), we also examined temporal patterns in habitat use by black sea bass. Our study site was located within the Historic Area Remediation Site (HARS), a $53.8 \mathrm{~km}^{2}$ area about $6.5 \mathrm{~km}$ off the coast of New Jersey, USA. The HARS encompasses the old 'mud dump site', which has received dredged materials from the Port of New York and New Jersey since the late 1800s. Diverse substrates and variations in bathymetry at the HARS provide a variety of habitats for black sea bass. The study site in the HARS includes areas of relatively homogeneous bottom as well as areas with highly variable bottom characteristics and topography, including rock outcrops near the central portion of the site (Schwab et al. 2000, Butman 2002). Some of these variations are due to natural processes, but others resulted from human activity, mainly disposal of dredged material, large rocks, and other debris. Sediments at the HARS range from fine-grain muddy sediments to coarse-grain material comprising sand, gravel, and rocks (Lathrop et al. 2006). Variations in sediment grain-size composition that occur on the scale of tens to hundreds of meters and topographic relief on the order of a few meters exist throughout the HARS (Butman 2002, Lathrop et al. 2006). Indeed, placed material at the HARS may form mounds as high as $6 \mathrm{~m}$, though typically relief is only a few meters (Butman 2002).

Together with information on sediment characteristics and bathymetry at the HARS, acoustic data from individual fish were used to answer the following questions: Which areas of the HARS are used by black sea bass and for how long? What environmental factors are associated with dispersal from the HARS? Do fish exhibit sex-related differences in dispersal characteristics?

\section{MATERIALS AND METHODS}

\section{Acoustic grid}

In April 2003, prior to releasing fish with acoustic transmitters, we established a grid of 72 acoustic stations at the HARS. At each acoustic station we deployed an array that consisted of a $400 \mathrm{lb}$ $(\approx 181.44 \mathrm{~kg})$ pyramidal anchor, an acoustic receiver (model VR2, Vemco), and a shallow-water release encased in a positively buoyant canister (SWR popup recovery system, ORE Offshore). Arrays were placed $800 \mathrm{~m}$ apart, covered $46.1 \mathrm{~km}^{2}$ of the HARS (Fig. 1), and allowed us to examine habitat use and dispersal of black sea bass from the study site (Heupel et al. 2006). The inter-receiver distance was 

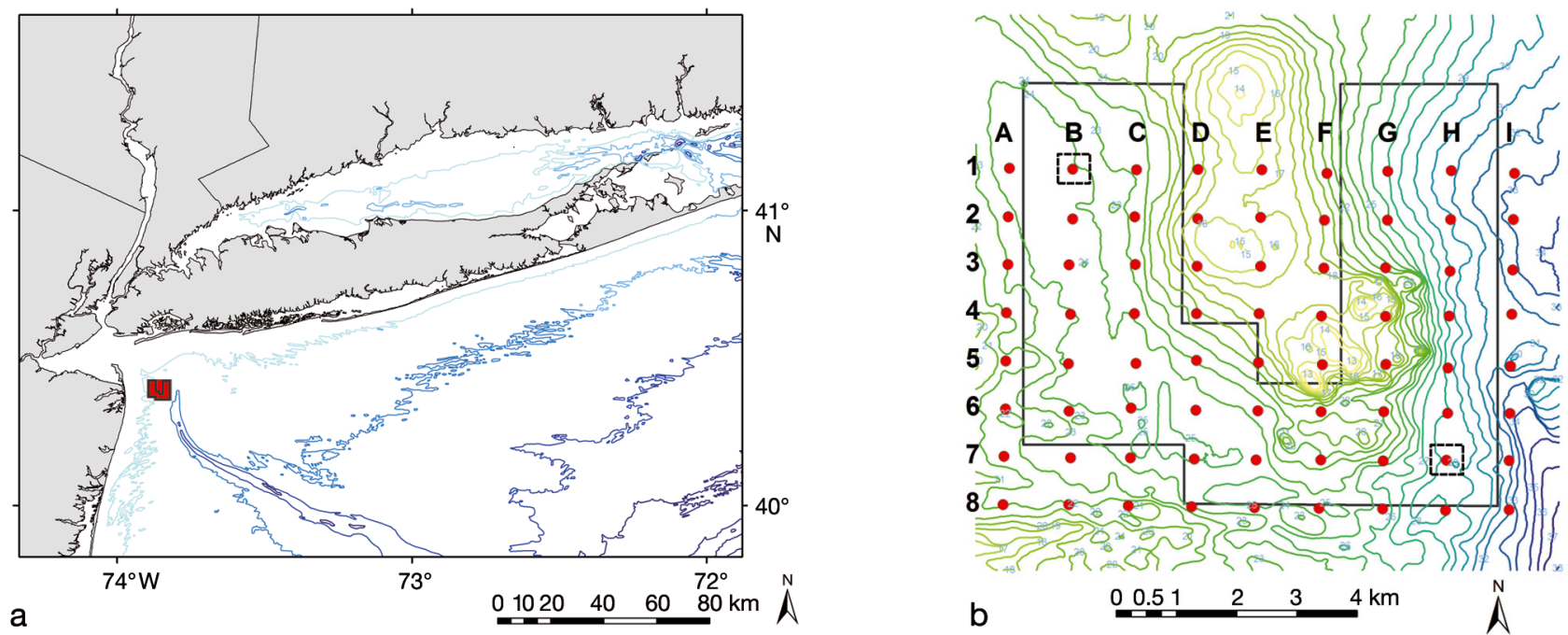

Fig. 1. (a) Location and bathymetry (20 m isobaths) of the Historic Area Remediation Site (HARS) in the mid-Atlantic Bight; the site (red polygon) is located $\sim 6.5 \mathrm{~km}$ east of Highlands, New Jersey, USA, and $14.3 \mathrm{~km}$ south of Rockaway, New York, USA. (b) Acoustic grid and bathymetry at the HARS; the grid encompasses $46.1 \mathrm{~km}^{2}$ of the HARS; the solid black line designates the area for material disposal, and the contour lines are $1 \mathrm{~m}$ isobaths. Column headings (A-I) and row designations (1-8) represent naming conventions for acoustic stations. Each acoustic receiver is designated by a red circle; squares at B1 and H7 indicate location of temperature sensors

determined from the results of a range test conducted in the southeastern portion of the site in October 2002. We used a single stationary acoustic receiver anchored $2 \mathrm{~m}$ above the seafloor and deployed a transmitter that emitted signals every $8 \mathrm{~s}$ (V8SC-2H transmitters; Vemco). The transmitter was deployed for $10 \mathrm{~min}$, near the surface and near the bottom, at 5 discrete distances between 100 and $560 \mathrm{~m}$ from the receiver. Results indicated at least $50 \%$ of the expected transmitter signals were detected at $400 \mathrm{~m}$.

Receivers were situated $2 \mathrm{~m}$ above the seafloor and oriented vertically, thus providing maximum horizontal sensitivity (Clements et al. 2005). Two arrays (Stns B1 and H7) also included a temperature sensor suspended $\sim 3 \mathrm{~m}$ above the substratum that recorded data every 30 min (SBE 16, Sea-Bird Electronics). To minimize damage to our instruments from ongoing placements of dredged material at the HARS (which occurred predominantly near the western edge of the site), the Army Corps of Engineers established a $76 \mathrm{~m}$ buffer zone around each array where disposal of remediation material was prohibited. We retrieved receivers once during the course of the year-long experiment to download data, as well as at the end of the experiment (summer 2004). Analyses of habitat associations and dispersal were based on acoustic data obtained from 30 May to 31 December 2003; acoustic data from 2004 were examined to document the return of fish to the HARS.

\section{Habitat characterization}

An analysis relating the presence of fish with the physical habitat characteristics of the HARS requires consideration of habitat features at the same spatial resolution as our fish detection data. We examined several bathymetric indices postulated to affect habitat use of black sea bass including indices of bottom 'roughness' or rugosity; all indices were calculated from high-resolution bathymetry data (Butman et al. 2002). Because the spatial resolution of the bathymetry data $(81 \times 81 \mathrm{~m})$ was at a finer scale than the acoustic data, we averaged the bathymetric information over the area encompassing the detection zone of each receiver $\left(400 \mathrm{~m}\right.$ radius, $\left.0.503 \mathrm{~km}^{2}\right)$. In this manner, we calculated mean depth, mean seabed slope (changes in depth), the variance of depth, and the variance of the seabed slope within each detection zone. The mean slope was intended to capture small-scale bathymetric variability, which may affect habitat use by fishes, especially on the inner continental shelf (Diaz et al. 2003).

Seafloor sediment characteristics interpreted by Lathrop et al. (2006) from USGS sidescan sonar data (resolution: $4 \times 4 \mathrm{~m}$ ) were also considered as an aid to understanding habitat affinity of black sea bass at the HARS. Various sediment types occur at the HARS including (1) coarse-grain, placed material; (2) coarsegrain coastal-plain sediment outcrop; (3) mediumgrain undifferentiated bottom sediments; (4) fine- to 
medium-grain undifferentiated bottom sediments; and (5) fine-grain shallow-water deposits. Because we were primarily interested in the effect of coarsegrain, placed material (dredged material) on black sea bass habitat use, we calculated the percentage of the detection zone comprising this sediment type.

\section{Surgical implantation of transmitters}

We used hook and line angling and commercial fish traps to capture 129 black sea bass at multiple locations within the HARS between 30 May and 16 July $2003\left(\mathrm{n}_{\text {traps }}=84 ; \mathrm{n}_{\text {angling }}=45\right)$. Traps were allowed to soak at the site for 1 to 3 nights before retrieval. As a result of pressure changes associated with capture, black sea bass swim bladders were inflated when the fish were brought on deck. Neither manual deflation of swim bladders with a hypodermic needle (Collins et al. 1999) nor 'hanging' of the traps at $10 \mathrm{~m}$ (Neufeld \& Spence 2004) alleviated decompression trauma for all fish. Therefore, to minimize handling (and stress), fish were immediately placed into onboard holding tanks supplied with flow-through seawater and held for surgical implantation.

We used $80 \mathrm{mg} \mathrm{l}^{-1}$ Aqui-S (Aqui-S New Zealand) to anesthetize fish prior to surgery; this concentration was required to minimize induction time (mean = $3.3 \mathrm{~min}$; range $=1.1$ to $7.7 \mathrm{~min} ; \mathrm{n}=127$ ). Anesthetic exposure and surgery were conducted at a mean water temperature of $17.8^{\circ} \mathrm{C}$ (range $=13.6$ to $24.2^{\circ} \mathrm{C}$ ) and $27.1 \mathrm{psu}$ salinity (range $=22.1$ to $31.0 \mathrm{psu}$ ). We implanted beeswax-coated V8SC-2H transmitters in 129 black sea bass (mean size $=307 \mathrm{~mm}$ total length [TL] [range $=220$ to $431 \mathrm{~mm} ; \mathrm{n}=129$ ], $408 \mathrm{~g}$ [range = 195 to $\left.995 g_{i} \mathrm{n}=91\right]$ ) at the HARS using surgical techniques previously established for this species (Fabrizio \& Pessutti 2007). Dummy transmitters of the same shape, size (30 mm long, $9 \mathrm{~mm}$ in diameter), and weight (5 $\mathrm{g}$ in air, $3.1 \mathrm{~g}$ in water) had 100\% retention rates in laboratory-held black sea bass (Fabrizio \& Pessutti 2007). Transmitters, which had a 384 d battery life, emitted a coded acoustic signal at $69 \mathrm{kHz}$ every $210 \mathrm{~s}$ on average (the delay between signals varied randomly between 120 and $300 \mathrm{~s}$ ). At the completion of the surgery, which required a mean of $4.1 \mathrm{~min}$ (range $=2.0$ to $11.7 \mathrm{~min} \mathrm{n}=128$ ), the length and sex of each fish was recorded, and an individually numbered T-bar anchor tag was inserted into the dorsal musculature. This external tag was imprinted with an identification number and a phone number for reporting recaptures. Some of the black sea bass in our study exhibited secondary sexual characteristics and were thus classified as male fish $(n=34)$, but the majority of fish were classified as 'unknowns', a group which included females and smaller males $(\mathrm{n}=88)$. Males were significantly larger than fish of unknown sex $\left(\bar{x}_{\text {male }}=343.5 \mathrm{~mm} \mathrm{TL}\right.$, $\mathrm{SE}=6.320 ; \bar{x}_{\text {unknown }}=292.5 \mathrm{~mm} \mathrm{TL}, \mathrm{SE}=4.454 ; t=$ $-6.23, \mathrm{p}<0.05)$. Fish were resuscitated using ram ventilation in a flow-through seawater tank onboard the vessel; as soon as fish were able to swim forcefully to the bottom of the tank, they were released within the HARS near the site of capture (Fig. 2). Although the swim bladder of some fish remained inflated during and after surgery, all released fish were observed swimming towards the sea floor upon release.

\section{Acoustic data}

For statistical analyses and modeling, we considered data from only the 122 live releases with functioning transmitters. Out of the 129 fish released at the HARS, 5 carried transmitters that were never detected; in addition, we ignored data from 2 transmitters because they were implanted in fish that died within a few hours of release (we inferred death when no movements were discerned as evidenced by the recording of detections by a single receiver). Redundant detections (i.e. those that occurred at the

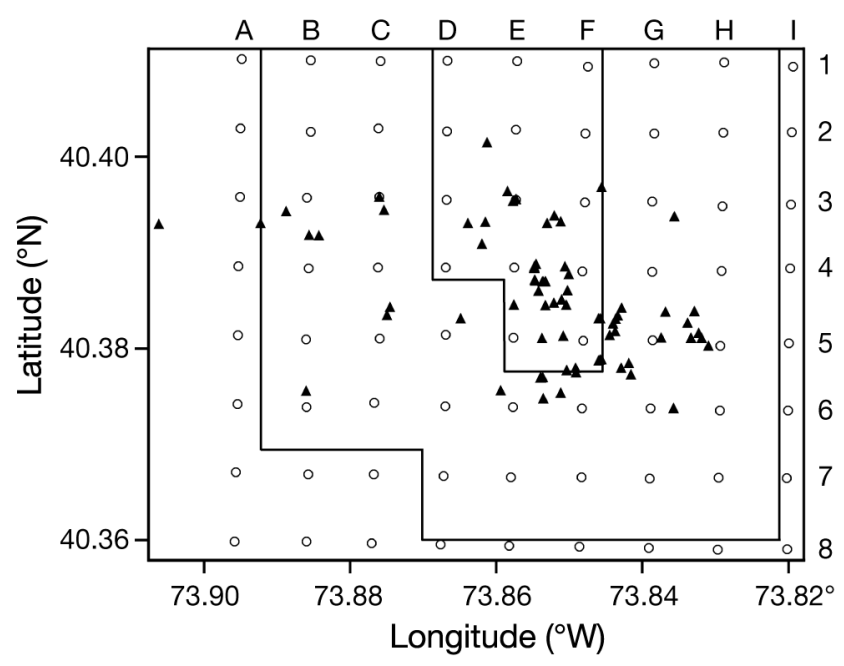

Fig. 2. Release locations ( $\mathbf{\Lambda}$ ) for 122 black sea bass Centropristis striata in summer 2003 at the Historic Area Remediation Site (HARS) (thin black lines, see Fig. 1); O: receiver locations; station designations (A-I; $1-8)$ are those from Fig. 1. One fish released outside the study area re-entered the acoustic grid at Stn A3 on the day of release and remained in the study area until 20 July 2003 
same time on adjacent receivers) were removed from consideration, as were single detections of a particular transmitter because such detections may have resulted from acoustic or environmental interference (Pincock \& Voegeli 2002). In a few cases we noted $<5$ detections from a given transmitter during a $24 \mathrm{~h}$ period; these were considered unreliable and thus also eliminated. From the initial retrieval of 1252573 detections from the period 30 May to 31 December 2003, we obtained 1007787 valid detections, representing 7 to 43067 detections per fish $($ mean $=8260.6, \mathrm{SE}=771.1503)$. Most $(86.7 \%)$ of these detections occurred in summer (30 May to 6 September) and from listening stations in shallow regions of the HARS (Fig. 3). In 2004, we obtained a total of 24 detections between 10 May and 21 June from 2 fish.

\section{Dispersal of black sea bass from the HARS}

We estimated the probability of dispersal of black sea bass from the HARS using the Kaplan-Meier (KM) estimator and acoustic data collected between late May and December 2003. The KM approach estimates the rate of change in the proportion of the sample population that remains at the study site (the complement of dispersal) during a particular sampling interval (Bennetts et al. 2001). The KM estimator is robust and the variance of this estimator is well described (Pollock et al. 1989a). The nonparametric $\mathrm{KM}$ estimator is appropriate for analyzing data that include censored observations; an observation is censored when the status is not known with certainty or when the individual is 'lost' from the study (Bennetts et al. 2001). Fish that were removed by anglers from the HARS and reported to us were censored, as was a single fish that died at the site $33 \mathrm{~d}$ after release. In addition, we censored all observations for which the last detection occurred at a non-perimeter station at the HARS; we reasoned that either (1) these fish were harvested and not reported to us, (2) these fish moved past a perimeter station undetected, or (3) the transmitter ceased to function. About $57.4 \%$ of the fish in this study represented censored observations, which contributed partial information to the estimate of dispersal.

Because tagged black sea bass were released over several weeks (30 May to 16 July 2003), we used the staggered entry extension for the KM estimator to analyze dispersal rates from the HARS (Pollock et al. 1989b). The number of fish at risk of dispersing, the number of fish that dispersed, the number of censored fish, and the number of newly added fish were tallied weekly between late May and December 2003 (29 wk). The probability of remaining at the HARS (i.e. not dispersing) was estimated as the ratio of tagged fish that did not disperse to the total number of tagged fish (alive and status known) available to disperse during that time interval (Bennetts et al.
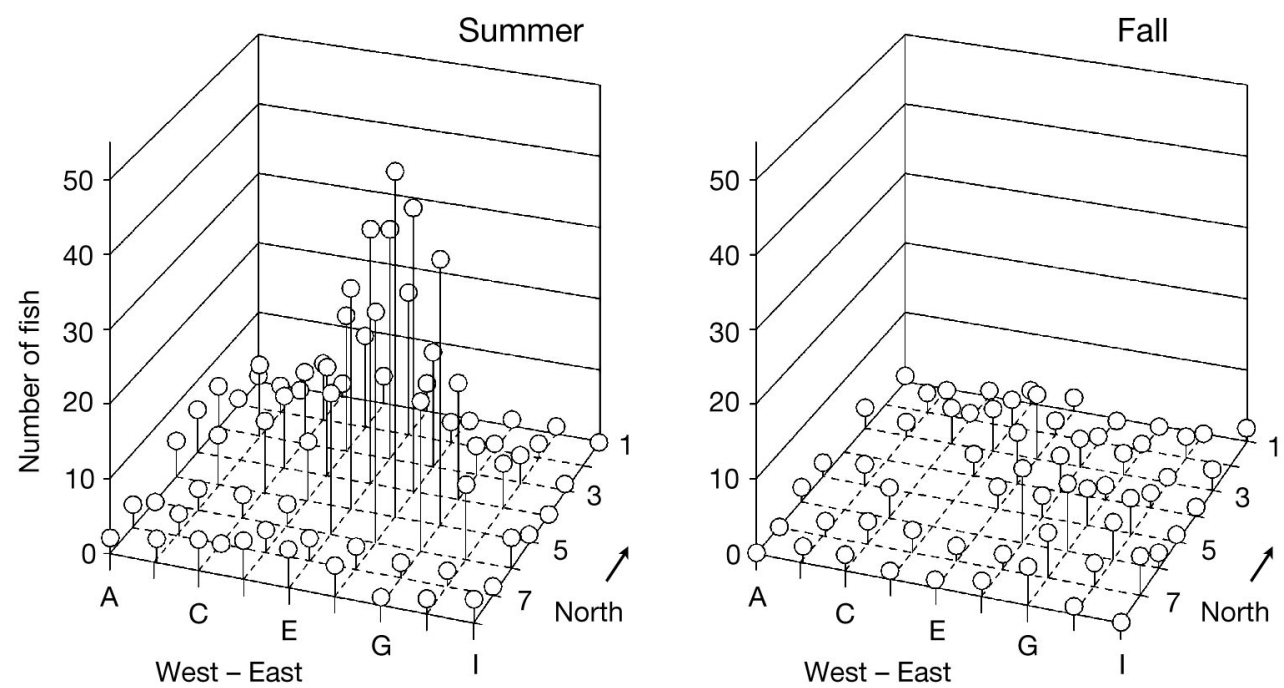

Fig. 3. Number of black sea bass Centropristis striata detected at listening stations in summer (30 May to 6 September) and fall (7 September to 31 December) 2003 at the Historic Area Remediation Site (HARS). In total, 122 black sea bass were released between 30 May and 16 July 2003; by fall, 54 fish remained at the site. Data were obtained from 70 receivers (B4 and I2 were never recovered), but due to our inability to recover all of our equipment in 2004, information from 12 receivers provided partial coverage (generally late May to late September 2003, but this varied depending on station) 
2001). The KM estimator, also known as the product limit estimator, is represented as:

$$
\hat{S}(t)=\prod_{j \mid a_{j}<t}\left(1-\frac{d_{j}}{r_{j}}\right)
$$

where $\hat{S}(t)$ is the probability of remaining at the HARS until time $t, d_{j}$ is the number of fish that dispersed from the HARS at time $a_{j,} r_{j}$ is the number of fish at risk of dispersing at time $a_{j}$, and the product is computed for all $j$ terms for which $a_{j}$ is less than time $t$ (Pollock et al. 1989b); the term $a_{j}$ is used because dispersals are observed at discrete time points but $t$ can be any arbitrary time. The estimate of the variance of the KM function is given by:

$$
\operatorname{var}[\hat{S}(t)]=\frac{[\hat{S}(t)]^{2}[1-\hat{S}(t)]}{r(t)}
$$

where $r(t)$ is the number of fish at risk of dispersing at time $t$ (Pollock et al. 1989b). Dispersal rates of male fish and fish of unknown sex were compared using the log-rank test; the test statistic $\left(W_{L}\right)$ has a $\chi^{2}$ distribution with 1 degree of freedom (Collett 2003).

\section{Habitat use}

Black sea bass occupied individual stations at the HARS in a significantly non-uniform manner, regardless of season $\left(\chi_{\text {summer }}^{2}=929.0, p<0.05 ; \chi_{\text {fall }}^{2}=109.8, p\right.$ $<0.05$ ). We therefore explored the relationship between the occurrence of black sea bass at individual stations and seafloor habitat characteristics at each station using a negative binomial regression (Dalthorp 2004, O'Farrell et al. 2009, Sutherland et al. 2010). The data we examined were the number of fish at each station during summer or fall (response); the percent of the area that comprised coarse-grain, placed material; mean depth; mean seafloor slope; variance of depth; and variance of the seafloor slope within the detection region surrounding each receiver. Daily observations corresponding to $<5$ detections of an individual fish at a given station were not considered in this analysis (thus, we used information from 996896 detections for modeling habitat use). We note that the position of individual fish within the detection range of a particular receiver was unknown, but our goal was to relate fish distribution patterns at the HARS to the average of the measured seafloor features in the area occupied by the fish. In addition to the fixed predictors characterizing bottom-habitat features, we included season as a factor in the model to allow for seasonal changes in habitat associations (e.g. Reebs 2002, Cote et al. 2003). Thus, each listening station at the HARS comprised an experimental unit, at which individual fish were counted and habitat features were measured $\left(\mathrm{n}_{\text {summer }}=69 ; \mathrm{n}_{\text {fall }}=62\right)$; information from 3 stations in summer and 10 in fall was not included in this analysis due to loss or malfunctioning of receivers. Prior to fitting habitat models to the acoustic data, we centered the seafloor habitat variables to remove the effects of collinearity. However, tolerance statistics (Quinn \& Keough 2002) estimated with the general linear model (GLM) procedure in SAS indicated strong evidence of collinearity between mean slope and variance of depth that was not removed by centering or other means of standardization; therefore, we constructed models with only one of these 2 predictors, but not both.

The negative binomial model with a single predictor, $X$, and a 'treatment' effect, $\tau$, is given by:

$$
\eta_{i j}=\log \left(\lambda_{i j}\right)=\mu+X \beta_{i}+\tau_{j}+\varepsilon_{i j}
$$

where $\eta_{i j}$ is the log of the mean response, $\lambda_{i j i} \mu$ is the intercept or overall mean response; $\beta_{i}$ is the slope of the regression relating the predictor (e.g. mean depth) to the log of the mean response; $\tau_{j}$ is the effect of the $j$ th treatment (season); and $\varepsilon_{i j}$ is a random vector of residual errors with an expected value of 0 (Littell et al. 2002). In this model, the response ( $y$ ) is assumed to follow a negative binomial distribution with $E(y)=\lambda$ and variance $(y)=\lambda+\lambda^{2} / k$, where $k$ is the aggregation parameter. Maximum likelihood estimates of model parameters were obtained using the GENMOD procedure in SAS (Littell et al. 2002). Adequacy of model fit was assessed with the Pearson $\chi^{2}$ goodness-of-fit statistic (Littell et al. 2002), and model selection was guided by Akaike's information criterion (AIC). Significance of predictors was assessed with the likelihood ratio $\chi^{2}$ statistic.

\section{RESULTS}

\section{Dispersal of black sea bass from the HARS}

Black sea bass dispersal from the HARS was greatest in early summer and again in late fall (Fig. 4a). Some black sea bass were present at the HARS for short periods $(<1 \mathrm{mo})$, whereas others resided at the HARS for up to 6 mo (175 d), indicating that individual reefs on the inner continental shelf may be used by this species for a considerable portion of the year. Black sea bass began dispersing from the HARS in early June and the likelihood of dispersal decreased about 35 d later in early July (Fig. 4a). During the time 

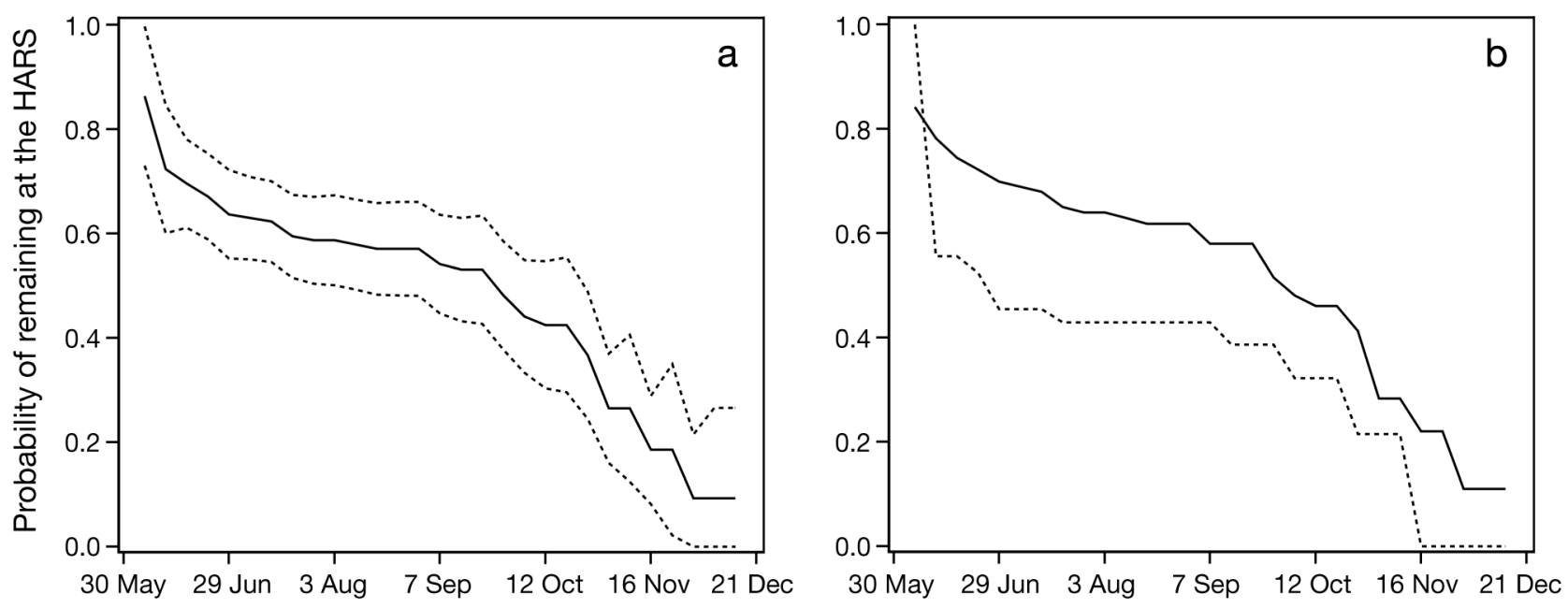

Fig. 4. Probability of black sea bass Centropristis striata (a) remaining at the Historic Area Remediation Site (HARS) (solid line) and 95\% confidence intervals (dashed lines) and (b) remaining at the HARS for male fish (dashed line) and fish of unknown sex (solid line); for clarity, confidence intervals are not included. Plots show dispersal between 30 May and 20 December 2003 (last detection occurred on 14 December). Probabilities were estimated using the Kaplan-Meier approach

we released tagged fish (30 May to 16 July 2003), and shortly thereafter (17 to 23 July 2003) 28 fish dispersed from the HARS: 3 were captured elsewhere by anglers, and 25 dispersed from the site through either the southern $(48 \%)$ or western $(28 \%)$ perimeters. Dispersal of fish between July and late September was low, but increased markedly thereafter such that by early November, about $74 \%$ of the implanted black sea bass had dispersed from the HARS (Fig. 4a). A large number of the remaining fish $(n=7)$ dispersed from the study area in mid-November when bottomwater temperatures in shallower nearshore waters fell consistently below those observed in deeper water on the eastern edge of the study area (Fig. 5). The last detection recorded at the HARS was on 14 December 2003 when bottom water temperatures averaged about 8.9 and $9.9^{\circ} \mathrm{C}$ at the inshore and offshore sites; the fish that was detected on 14 December had resided at the HARS for $175 \mathrm{~d}$. It is unclear when or if this fish dispersed from the HARS because it was not detected moving past a perimeter station.

Dispersal likelihoods for males $(n=34)$ and fish of unknown sex $(\mathrm{n}=88)$ during the 29 wk study were not significantly different $\left(\chi^{2}=1.357, p=0.24\right.$; Fig. $\left.4 b\right)$. We attribute this to the large confidence intervals around the estimates of sex-specific dispersal probabilities, which most likely resulted from the high number of censored observations. Another factor contributing to the observed uncertainty is the mixed nature of the group of fish of unknown sex, which included females and immature males. However, our data suggest that during June about $54 \%$ of males but only $30 \%$ of the unknowns had dispersed (Fig. 4b); this difference was marginally significant $\left(\chi^{2}=3.418\right.$, $\mathrm{p}=0.06$ ).

After dispersing to offshore waters in winter, 2 black sea bass returned to the HARS in 2004. One male fish dispersed from the HARS on 17 November 2003 and was detected on 13 May 2004. A fish of unknown sex that was last detected on 23 November 2003 returned to the HARS and was detected on multiple occasions between 10 May and 21 June 2004. Both fish returned to the HARS when mean water temperatures on the mid-Atlantic continental shelf consistently exceeded $8^{\circ} \mathrm{C}$ (station 44025 Long Island Data Buoy, NOAA National Data Buoy Center).

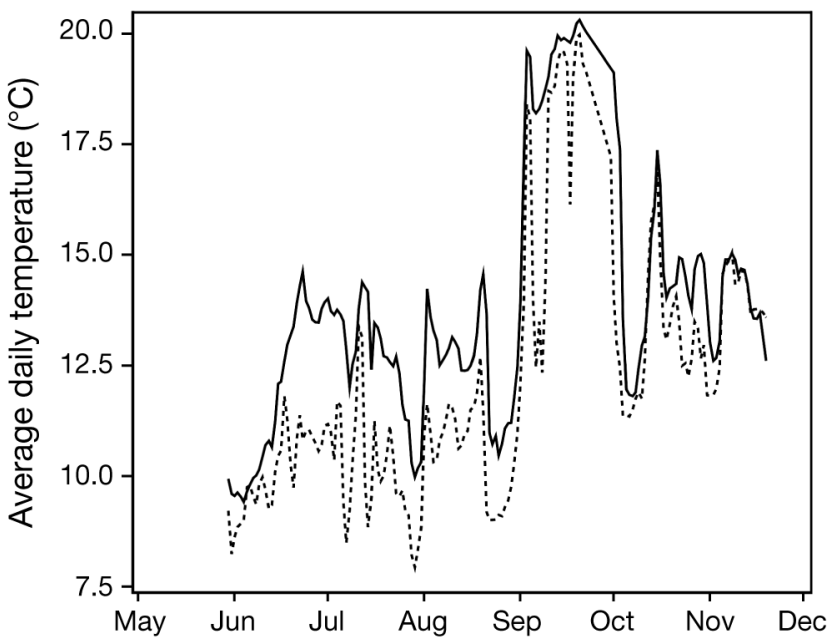

Fig. 5. Average daily temperature at Historic Area Remediation Site (HARS) Stns B1 (solid line) and H7 (dashed line) from 30 May to 19 November 2003. Station locations are depicted in Fig. 1 


\section{Habitat use by black sea bass}

Black sea bass were significantly more likely to use the HARS in summer than in fall $\left(\right.$ mean $_{\text {summer }}=8.41$ fish per station, $\mathrm{SE}=1.290 ;$ mean $_{\text {fall }}=2.79$ fish per station, $\mathrm{SE}=0.285 ; F=16.37$, p $<0.01$; Fig. 3). In summer, 20 or more fish per day were detected at 6 stations (Stns E4, E5, F4, F5, F6, G5); these occurrences were not common, and were observed an average of $2.15 \mathrm{~d}$ $(\mathrm{SE}=0.2083$; range $=1$ to $8 \mathrm{~d}$ ) at these stations. On average, $10.61 \mathrm{fish}^{-1}$ ( $\mathrm{SE}=0.8833$ ) were detected at these 6 stations in summer and 1.92 fish $d^{-1}(\mathrm{SE}=$ $0.7544)$ were detected in fall - a difference that was significant $(F=55.97, \mathrm{p}<0.01)$. The maximum number of fish detected per day at a given station occurred on 24 and 25 June, when 35 fish were detected at Stn F5.

Black sea bass were more likely to be associated with coarse, placed sediments in areas of highly variable bottom topography (Fig. 3). Physical characteristics at the HARS varied widely among the 72 stations, with an average of $26.8 \%$ of sediment comprising coarse-grain, placed material and an average depth of $25.5 \mathrm{~m}$ (Table 1). As expected, the proportion of placed material was negatively correlated with the proportion of other sediment types. The 6 stations occupied most frequently by individual fish contained a significantly greater mean proportion of coarse-grain, placed material $($ mean $=50.4 \%, \mathrm{SE}=$
Table 1. Physical characteristics of the 72 acoustic stations at the Historic Area Remediation Site (HARS) calculated from geo-referenced continuous coverage data within $400 \mathrm{~m}$ of the receiver. Composition of bottom sediment was obtained from Lathrop et al. (2006); mean depth, variance of the depth, mean slope (change in depth), and variance of the slope were calculated from high-resolution bathymetry data obtained from the NOAA National Geophysical Data Center and described in Butman et al. (2002). These data had a $100 \mathrm{~m}^{2}$ resolution, and each station was characterized by either a mean or variance estimated from data from multiple grid cells

\begin{tabular}{|lcc|}
\hline Physical characteristic & Mean & Range \\
\hline $\begin{array}{l}\text { Proportion of sediment (\%) } \\
\text { classified as coarse-grain, }\end{array}$ & 26.82 & $0-80.9$ \\
$\begin{array}{l}\text { placed material } \\
\text { Mean depth (m) }\end{array}$ & & \\
Variance of the depth & 25.46 & $16.99-33.67$ \\
Mean slope of the bottom & 2.015 & $0.026-15.882$ \\
Variance of the slope & 0.505 & $0.106-1.562$ \\
& 0.196 & $0.004-2.196$ \\
\hline
\end{tabular}

5.9350) than other HARS stations (mean $=24.5 \%$, $\mathrm{SE}=3.2256 ; F=5.81, \mathrm{p}=0.02$ )

Habitat use (station occupancy) at the HARS was described by a model that included season, percent of area comprising coarse-grain, placed material, mean depth, variance of the mean seafloor slope, and the interaction between percent coarse material and mean depth (Table 2). This model fit the data well as

Table 2. Models describing habitat associations of black sea bass Centropristis striata at a mid-Atlantic Bight reef, May to December 2003. The response was the total number of fish at each station detected in summer or fall, and was assumed to follow a negative binomial distribution. Black sea bass could potentially occupy 69 stations in summer and 62 stations in fall. Predictors considered in the model included: season, mean slope (estimated from bottom topography), mean depth, variance of the slope (var slope), variance of depth (var depth), and the proportion of coarse-grain, placed material (sed). The values for the continuous predictors are the mean, variance, or proportion of the bottom within a $400 \mathrm{~m}$ radius of the listening station. The number of parameters is the number of predictors plus one (one parameter for each effect plus the dispersion parameter). Values of the Pearson $\chi^{2} / \mathrm{df}$ near 1.0 indicate a good fit of the model. The model with the lowest AIC (Akaike's information criterion) was selected

\begin{tabular}{|c|c|c|c|}
\hline Predictors & AIC & $\Delta \mathrm{AIC}$ & Pearson $\chi^{2} / \mathrm{df}$ \\
\hline Season + sed + mean depth + var slope + sed $\times$ mean depth & 685.98 & 0 & 0.985 \\
\hline Season + sed + mean depth + var slope + sed $\times$ mean depth + sed $\times$ var slope & 686.77 & 0.79 & 1.029 \\
\hline Season + sed + mean depth + sed $\times$ mean depth & 687.12 & 1.14 & 0.916 \\
\hline Season + sed + mean depth + var slope + sed $\times$ mean depth + sed $\times$ season & 687.84 & 1.86 & 0.989 \\
\hline Season + sed + mean depth + var slope + sed $\times$ season + sed $\times$ mean depth + sed $\times$ var slope & 688.68 & 2.70 & 1.035 \\
\hline Season + sed + mean depth + mean slope + sed $\times$ mean depth & 688.76 & 2.78 & 0.943 \\
\hline Season + sed + mean depth + sed $\times$ season + sed $\times$ mean depth & 688.95 & 2.97 & 0.920 \\
\hline $\begin{array}{l}\text { Season }+ \text { sed }+ \text { mean slope }+ \text { mean depth }+ \text { var slope }+ \text { sed } \times \text { season }+ \text { sed } \times \text { mean depth }+ \\
\text { sed } \times \text { var slope }\end{array}$ & 689.65 & 3.67 & 1.030 \\
\hline $\begin{array}{l}\text { Season }+ \text { sed }+ \text { mean slope }+ \text { mean depth }+ \text { var slope }+ \text { sed } \times \text { season }+ \text { sed } \times \text { mean slope }+ \\
\text { sed } \times \text { mean depth }+ \text { sed } \times \text { var slope }\end{array}$ & 690.51 & 4.53 & 1.037 \\
\hline Season + sed + mean slope + mean depth + var slope & 695.72 & 9.74 & 1.010 \\
\hline Season + sed + mean depth & 697.78 & 11.80 & 0.939 \\
\hline $\begin{array}{l}\text { Season }+ \text { sed }+ \text { mean slope }+ \text { mean depth }+ \text { var slope }+ \text { season } \times \text { sed }+ \text { season } \times \text { mean slope }+ \\
\text { season } \times \text { mean depth }+ \text { season } \times \text { var slope }\end{array}$ & 698.74 & 12.76 & 1.035 \\
\hline Season + sed + mean slope + mean depth & 698.97 & 12.99 & 0.969 \\
\hline Season + sed + mean slope + var slope & 699.14 & 13.16 & 0.949 \\
\hline
\end{tabular}


evidenced by a non-significant goodness-of-fit test (Pearson $\chi^{2}=123.149, \mathrm{df}=125, \mathrm{p}=0.53$ ), indicating a lack of difference between the station-specific predicted and expected number of detections. Significant model predictors were season $\left(\chi_{\text {season }}^{2}=31.07\right.$, $p<0.05)$ and the interaction of the proportion of coarse-grain, placed material and mean depth $\left(\chi^{2} \%\right.$ coarse $\times$ mean depth $\left.=11.08, p<0.05\right)$; the variance of the slope was marginally significant $\left(\chi_{\text {var(slope })}^{2}=3.15\right.$, $p=0.08)$. The predicted number of fish per station was about 2.7 times lower in the fall than that predicted for summer $\left(1 / \mathrm{e}^{-0.9922}\right)$, and regardless of season, the number of fish tended to increase with increasing variation in seafloor slope.

In addition to strong seasonal differences and an affinity for highly variable bathymetry, fish were more likely to use stations with a greater proportion of coarse-grain, placed material; however, this was strongly mediated by depth (significant interaction term). In waters $\leq 27.5 \mathrm{~m}$, the number of black sea bass using a station increased with increasing proportion of coarse-grain material; in deeper waters, the proportion of coarse-grain sediments did not affect the number of fish at a station (Fig. 6). Taken together, these results suggest that at the HARS, black sea bass are more likely to occupy shallow areas with a greater proportion of coarse-grain, placed material. Several stations along the eastern portion of the HARS (Stns H2, H7, H8, I3, I4, I5, I6, I7, I8) con-

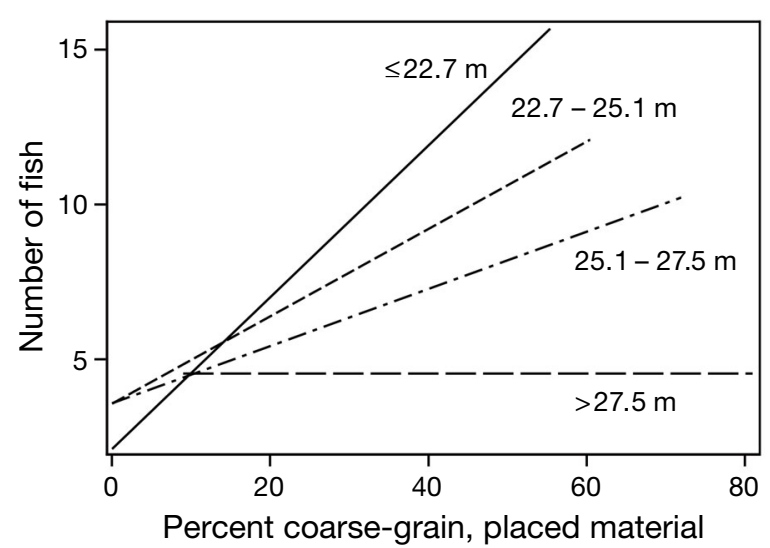

Fig. 6. Model-based relationships between the predicted number of black sea bass Centropristis striata at the Historic Area Remediation Site (HARS) in 2003 and the proportion of area surrounding the listening station that comprised coarse-grain, placed material. The predicted number of fish increased significantly with increasing proportion of coarse-grained, placed material at shallow $(\leq 22.7 \mathrm{~m})$ and intermediate depths $(22.71-27.5 \mathrm{~m})$, but was not significantly affected by sediment composition where depths exceeded $27.5 \mathrm{~m}$ (the slope of this line was not significant: $t=-1.50, \mathrm{p}=0.142$ ) tained $>50 \%$ coarse-grain, placed material but these stations were in deep water $(31.3 \mathrm{~m}$ mean depth, $\mathrm{SE}=0.669$ ) and rarely used by fish in summer (mean number of fish per station $=1.0, \mathrm{SE}=0.236$ ). In contrast, Stns C3, D3, E3, E4, F1, F3, F4 and F5, which also comprised $>50 \%$ coarse-grain placed materials, were shallower $(22.5 \mathrm{~m}$ mean depth, $\mathrm{SE}=1.323)$ and more frequently used by black sea bass in summer (mean number of fish per station $=11.3, \mathrm{SE}=2.839)$. During summer, only 9 fish used deep stations with coarse-grain, placed material, whereas 90 fish used shallow stations with coarse-grain, placed material.

\section{DISCUSSION}

Individual black sea bass used reefs on the inner continental shelf for variable and prolonged periods of time (up to $6 \mathrm{mo}$ ) that encompassed the spawning period; as such, these habitats may be critically important to the continued production of the stock. A small proportion of fish known to have dispersed from our study site in 2003 returned the following spring ( $4 \%$, or 2 out of 53 fish), suggesting that black sea bass may use the same inshore reef for spawning and feeding in multiple years. Estimates of site fidelity for this species are difficult to obtain with acoustic telemetry data because such studies typically employ small numbers of tagged fish $(<100)$. Conventional tagging studies can be used instead, and such studies indicate a high degree of site fidelity to inshore regions. In particular, $\sim 50 \%$ of the fish tagged in the region between central Long Island and the mouth of Chesapeake Bay returned to locations within $10 \mathrm{~km}$ of the release site; however, individual reef fidelity was not estimated (Moser \& Shepherd 2009).

The timing of dispersal of black sea bass from inshore habitats varies with life history stage (Musick \& Mercer 1977), but among age 1+ fish, dispersal to offshore wintering habitats appears to be size invariant. Young-of-the-year fish disperse from nearshore, shelf habitats before larger, older fish (Musick \& Mercer 1977). In our study, size and sex of fish were confounded, which precluded testing of size effects on dispersal rates. However, dispersal of fish from the HARS in the fall did not differ between males, which were larger on average, and fish of unknown sex, suggesting a lack of fish size effects on the timing of offshore movements.

The fall dispersal of black sea bass from the HARS supports the previously described seasonal migration pattern for this species; however, we also observed 
dispersal of black sea bass from the HARS in early summer (30 May to 5 July). During this time, black sea bass dispersed by way of the western and southern perimeters of the site; most of these fish were males and we speculate that such movements may be related to sex-specific pre-spawning behaviors of this species. These males may have been searching for spawning or foraging habitats at other nearshore reefs, such as Shrewsbury Rocks, a rocky reef off the central New Jersey coast known to support a recreational fishery for black sea bass (Steimle \& Zetlin 2000). Among haremic fishes (including several species of serranids), males establish and defend territories, and females form harems in association with dominant males. Although such behaviors have not been documented in the wild for black sea bass, spawning behavior of laboratory-held black sea bass was similar to that of other haremic fishes wherein a single, dominant male controls spawning by segregating female fish from subordinate males (Nelson et al. 2003). Mature males that remained at the HARS throughout the summer presumably established and maintained territories, but males that left the HARS in early summer may have sought suitable spawning territories elsewhere. Females on their shoreward migration to spawning and feeding areas may have joined established harems at the HARS and remained in these habitats; small males may exhibit movement behaviors similar to females, remaining at the HARS throughout the summer. These sex-related differences in pre-spawning behaviors may account for the off-site directed movement we observed among mature males in early summer. Such movements are consistent with those reported for conventionally tagged black sea bass in the mid-Atlantic Bight (Moser \& Shepherd 2009).

The large-scale cross-shelf migration of black sea bass in fall is hypothesized to be in response to temperature (Moser \& Shepherd 2009), but our data suggest that other environmental factors may be at play. Off the New Jersey coast, black sea bass dispersed from the HARS throughout the fall, and these movements continued until bottom water temperatures declined to $\sim 9-10^{\circ} \mathrm{C}$. Off the coast of Virginia, black sea bass move offshore to wintering habitats when bottom water temperatures approach 7 to $8^{\circ} \mathrm{C}$ in the fall (Musick \& Mercer 1977, Colvocoresses \& Musick 1984); in the mid-Atlantic Bight, movements were reported to begin in fall when bottom water temperatures were 10 to $12^{\circ} \mathrm{C}$ (Moser \& Shepherd 2009). In our study, mean bottom water temperatures at the HARS were highest during September, exceeding $19^{\circ} \mathrm{C}$ at both inshore and offshore sites between 13 and 22 September
2003 (Fig. 5). After late September, fish dispersal likelihoods increased but mean bottom water temperatures remained $>11.4^{\circ} \mathrm{C}$, suggesting that other environmental factors may serve as cues. In addition, our analyses do not suggest a 'mass exodus' of fish triggered by an abrupt temperature change, but rather, dispersal likelihoods exhibited a fairly steady rate of decline between late-September and mid-December, as bottom water temperatures in inshore areas decreased. Gradual dispersal of juvenile Atlantic cod was similarly observed in coastal Newfoundland, with migrations to deeper waters commencing at the disappearance of the thermocline and continuing for several weeks thereafter (Cote et al. 2004). We hypothesize that dispersal from the HARS in fall may be cued by both temperature and photoperiod. Furthermore, black sea bass are known to use both of these cues to initiate spawning. In captive fish, spawning is induced at 18 to $20^{\circ} \mathrm{C}$ and under a photoperiod consisting of $15 \mathrm{~h}$ of light and $9 \mathrm{~h}$ of darkness (Howell et al. 2003, Nelson et al. 2003). Although we do not know with certainty when spawning occurred at the HARS, black sea bass from the New York Bight exhibited the highest gonadosomatic indices during July (Wilk et al. 1990); however, this observation was based on small sample sizes. In 2003, mean daily bottom water temperatures approached 18 to $20^{\circ} \mathrm{C}$ only in September, and it was not until the first week of September that $15 \mathrm{~h}$ of daylight was observed. Relative to dispersal during summer, we noted a substantial increase in dispersal of fish in late September, which is shortly after ideal spawning conditions occurred at the HARS. The observed increase in dispersal was most likely due to fish moving offshore toward deeper winter habitats on the continental shelf (Musick \& Mercer 1977, Moser \& Shepherd 2009).

In our dispersal analysis, we censored observations for which the fate of the fish was unknown, including fish that were last detected at an interior station of the acoustic grid. It is possible that some of these fish crossed one of the perimeter stations undetected. Based on maximum swimming speeds of black sea bass observed in the laboratory and on the ping rate of our transmitters, a fast-swimming fish would emit at least 5 acoustic signals while traversing a perimeter station (Fabrizio et al. 2005). However, because sound detection is complex, and because detection ranges of receivers vary in response to environmental variation, such transmissions may have been undetected. The only objective means to establish off-site dispersal of a fish that was last detected at an interior station would be from information on the fate of the fish from outside of the 
HARS. For example, if a fisher reports the capture of a tagged fish outside the HARS, then it is reasonable to assume that the fish left the HARS (undetected). Unfortunately, the single fish that was intercepted and reported to us by a recreational angler in 2003 had a failed transmitter, and therefore was not included in the dispersal analysis.

We believe that some of the censored fish in our study resulted from non-detection of the transmitter due to transmitter failure, environmental variability affecting detection, or harvesting and non-reporting by anglers. During summer and fall, fishing pressure for black sea bass at the HARS is intense (M. C. Fabrizio pers. obs.) and $89.2 \%$ of our censored observations were from fish last detected at one of the stations in the area most heavily fished by recreational anglers (Stns D3-4, E3-4-5, F4-5-6, and G3-4-5-6); this area is easily recognizable because of the yellow 'NY' buoy (the Mud Buoy) that marks the mud dump site at the reef. A small number of censored fish, $\mathrm{n}=13$, was recaptured and reported to us. These recaptured fish represent $10.7 \%$ of the total number of live, implanted black sea bass released at the HARS, and compares favorably with the $13.1 \%$ recapture rate reported for black sea bass tagged and released off Long Islandnorthern New Jersey in 2002-2003 (NEFSC 2004). Of the reports we obtained from anglers, most reported capturing and releasing the fish, but our acoustic data indicate that such information was not entirely reliable (often, capture dates were not reported, and if released, some fish were apparently not released at the HARS, or they were not released at all). We believe that the $10.7 \%$ recapture rate estimated here is biased low because reporting rates were not $100 \%$; additional tagged fish were likely to have been removed from the HARS and not reported. Using the $67.7 \%$ reporting rate estimated in the stock assessment (NEFSC 2004) for New Jersey-Delaware fishers, we would have expected 19 tagged fish to be harvested. This number is much lower than the number of censored fish $(\mathrm{n}=70)$, i.e. fish whose fate was unknown, suggesting a large proportion of censored fish could not be accounted for by lack of reporting. Three scenarios may have produced the observed discrepancy between the number of reported recaptures and the number of censored fish: (1) the reporting rate for fish captured near the HARS is significantly lower (around $15.7 \%$ ) than that estimated in the stock assessment for this region (NEFSC 2004); (2) reporting rates are significantly lower and exploitation rates are significantly higher at the HARS than the overall rates estimated from Massachusetts to North Carolina; or (3) fish were undetected due to transmitter failure or variations in the detection range of receivers along the perimeter stations. Without additional tagging studies targeting individual reefs, we cannot be certain if lower reporting rates alone resulted in the large number of censored observations in our study. However, these results underscore the need for better reefspecific information concerning angler behaviors.

The distribution of black sea bass at the HARS was not random and fish were detected most frequently at relatively shallow $(\leq 27.5 \mathrm{~m})$ sites of varying bathymetry containing previously placed, coarse-grain material. Such shallow, complex habitats occurred primarily in the central region of the HARS. Based on the high topographic relief and high backscatter reflectance, this area is believed to comprise a mosaic of rock outcrops and softer substrates (Butman 2002). The presence of previously placed, coarsegrain material in shallow water was a good predictor of habitat use by black sea bass, indicating that such material may have been colonized by potential invertebrate prey, or created areas of high relief sought by fish, or both. Such habitats may be formed as a result of individual placements of dredged material, which are clearly discernible in high-resolution maps of the seafloor (see Butman 2002).

Habitat associations of fishes may vary over time and depend on the spatial scale of observation (Crook et al. 2001). The $>2$-fold decrease in habitat use that we detected in the fall for black sea bass at the HARS was most likely related to the dynamics of dispersal from the inner shelf because areas occupied in summer and fall were similar, at least on the scale measured in this study. Seasonal variation in habitat use may result if individual black sea bass use deeper waters in the fall (including deeper sites outside of our acoustic grid); if this were the case, then we would have found a greater proportion of resident fish at the deeper HARS stations in the fall relative to summer. We did not observe this on an individual fish level: $37.0 \%$ (20 of 54) of black sea bass used deep habitats in the fall, whereas $39.3 \%$ (48 of 122) of fish used deep habitats in summer.

Although patterns of habitat association observed at the HARS were consistent with those reported previously for this species, we also documented that black sea bass use areas that comprised previously placed, coarse-grain material. Black sea bass use temperate reefs of the mid-Atlantic shelf for spawning, resting, and refuge from predation, but they feed primarily on benthic invertebrates on adjacent soft substrates (Steimle \& Figley 1996). Black sea bass may also be found in sandy habitats, but abundance in these areas is significantly lower (Eklund \& Tar- 
gett 1991). In our study, 18 individuals were detected at stations in the southwestern region of the HARS where large sand waves occur (Schwab et al. 2000). These sand waves are conspicuous features south and west of the HARS, as well as south of Long Island and east of the Delmarva Peninsula. Assessing the relative abundance of black sea bass from inshore areas during summer when fish are vulnerable to both commercial trap fisheries and recreational harvests will be best achieved using approaches that permit sampling of structurally complex and bathymetrically varying habitats. Suitable estimates of abundance may be provided using traps, or visual surveys conducted by divers (Parker et al. 1994, Kendall et al. 2008) or from submersibles (Anderson \& Yoklavich 2007, O'Farrell et al. 2009). Our modeling results indicate that such surveys should be focused on reefs in relatively shallow areas $(<28 \mathrm{~m})$ during July and August, as fish tend to occupy these habitats more readily and for extended periods of time. In addition, video sampling may shed light on the effects of local density on pre-spawning and spawning behaviors of black sea bass, thereby improving our understanding of the carrying capacity of individual reefs.

Acknowledgements. We thank A. Draxler (retired, NOAANMFS) and A. Bejda (retired, NOAA-NMFS) for early discussions that helped us formulate this study; R. Lathrop (Center for Remote Sensing and Spatial Analysis, Rutgers University, New Brunswick, NJ) for seafloor habitat data; K. Pollock (North Carolina State University, Raleigh, NC) for providing software to implement the KM staggered entry design; and D. Mountain and M. Taylor (NOAA-NMFS, Woods Hole, MA) for loaning us the CTDs and providing technical support. We are grateful to Commander E. Christman, S. Smith, M. Moser (NOAA Marine Operations Center), and crew of the NOAA Vessel 'Thomas Jefferson' for assisting with array retrievals. We gratefully acknowledge the contributions of A. Drohan, A. Pollack, P. Shaheen, J. Rosendale, J. Hilbert, J. Sibunka, and F. Morello. We thank the captains and crew that supported our work on the RV 'Gloria Michelle', RV 'Nauvoo', RV 'Walford', RV 'Loosanoff', and MV 'Samantha Miller'; LT S. Sirois (NOAA) and Captain W. Ihde (Miller's Launch, New York City) provided critical logistical expertise during the field implementation of this work. This study was funded by the US Army Corps of Engineers; we thank T. Bridges (USACE, Engineer Research and Development Center, Vicksburg, MS), M. Greges (USACE, New York District, New York City), and S. Knowles (USACE, New York District, New York City) for coordination of our field work with ongoing ACOE activities at the HARS. We thank G. Shepherd (NOAA-NMFS, Woods Hole, MA) and 4 anonymous reviewers for comments that helped improve the paper. This research was conducted in accordance with guidelines on the use of animals in research published by the American Fisheries Society and the American Society of Ichthyologists and Herpetologists. This paper is contribution number 3266 of the Virginia Institute of Marine Science, The College of William and Mary.

\section{LITERATURE CITED}

Anderson TJ, Yoklavich MM (2007) Multiscale habitat associations of deepwater demersal fishes off central California. Fish Bull 105:168-179

Bennetts RE, Nichols JD, Lebreton JD, Pradel R, Hines JE, Kitchens WM (2001) Methods for estimating dispersal probabilities and related parameters using marked animals. In: Clobert J, Nichols JD, Danchin E, Dhondt A (eds) Dispersal. Oxford University Press, Oxford, p 3-17

Butman B (2002) Mapping the seafloor of the Historic Area Remediation Site (HARS) offshore of New York City. US Geological Survey Fact Sheet 001-02. Available at http://pubs.usgs.gov/factsheet/fs001-02/

Butman B, Danforth WW, Knowles SC, May B, Serrett L (2002) Seafloor topography and backscatter intensity of the Historic Area Remediation Site (HARS), offshore of New York, based on multibeam surveys conducted in 1996, 1998, and 2000. US Geological Survey Open-File Report 00-503. Available at http://pubs.usgs.gov/of/ 2000/of00-503

> Clements S, Jepsen D, Karnowski M, Schreck CB (2005) Optimization of an acoustic telemetry array for detecting transmitter-implanted fish. N Am J Fish Manag 25: 429-436

Collett D (2003) Modelling survival data in medical research, 2nd edn. Chapman \& Hall, New York, NY

Collette B, Klein-MacPhee G (2002) Bigelow and Schroeder's fishes of the Gulf of Maine, 3rd edn. Smithsonian Institution Press, Washington, DC

> Collins MR, McGovern JC, Sedberry GR, Meister HS, Pardieck R (1999) Swim bladder deflation in black sea bass and vermilion snapper: potential for increasing postrelease survival. N Am J Fish Manag 19:828-832

Colvocoresses JA, Musick JA (1984) Species associations and community composition of Middle Atlantic Bight continental shelf demersal fishes. Fish Bull 82:295-313

> Cote D, Ollerhead LMN, Scruton DA, McKinley RS (2003) Microhabitat use of juvenile Atlantic cod in a coastal area of Newfoundland determined by 2D telemetry. Mar Ecol Prog Ser 265:227-234

Cote D, Moulton S, Frampton PCB, Scruton DA, McKinley RS (2004) Habitat use and early winter movements by juvenile Atlantic cod in a coastal area of Newfoundland. J Fish Biol 64:665-679

Crook DA, Robertson AI, King AJ, Humphries P (2001) The influence of spatial scale and habitat arrangement on diel patterns of habitat use by two lowland river fishes. Oecologia 129:525-533

> Dalthorp D (2004) The generalized linear model for spatial data: assessing the effects of environmental covariates on population density in the field. Entomol Exp Appl 111: $117-131$

> Diaz RJ, Cutter GR Jr, Able KW (2003) The importance of physical and biogenic structure to juvenile fishes on the shallow inner continental shelf. Estuaries 26:12-20

> Douglas SG, Chaput G, Hayward J, Sheasgreen J (2009) Prespawning, spawning, and postspawning behavior of striped bass in the Miramichi River. Trans Am Fish Soc 138:121-134

- Eklund AM, Targett TE (1991) Seasonality of fish catch rates and species composition from the hard bottom trap fishery in the Middle Atlantic Bight (US east coast). Fish Res 12:1-22

> Fabrizio MC, Pessutti JP (2007) Long-term effects and recovery from surgical implantation of dummy transmitters in two marine fishes. J Exp Mar Biol Ecol 351:243-254 
Fabrizio MC, Pessutti JP, Manderson JP, Drohan AF, Phelan BA (2005) Use of the Historic Area Remediation Site by black sea bass and summer flounder. US Dept Commerce, Northeast Fish Sci Cent Ref Doc 05-06, NOAA, Woods Hole, Massachusetts. Available at www.nefsc. noaa.gov/nefsc/publications/crd/crd0506/

> Hammerschlag-Peyer CM, Layman CA (2010) Intrapopulation variation in habitat use by two abundant coastal fish species. Mar Ecol Prog Ser 415:211-220

Heupel MR, Semmens JM, Hobday AJ (2006) Automated acoustic tracking of aquatic animals: scales, design and deployment of listening station arrays. Mar Freshw Res 57:1-13

> Howell RA, Berlinsky DL, Bradley TM (2003) The effects of photoperiod manipulation on the reproduction of black sea bass, Centropristis striata. Aquaculture 218:651-669

Kendall MS, Bauer LJ, Jeffrey CFG (2008) Influence of benthic features and fishing pressure on size and distribution of three exploited reef fishes from the southeastern United States. Trans Am Fish Soc 137:1134-1146

Knip DM, Heupel MR, Simpfendorfer CA (2012) Habitat use and spatial segregation of adult spottail sharks Carcharhinus sorrah in tropical nearshore waters. J Fish Biol 80:767-784

> Lathrop RG, Cole M, Senyk N, Butman B (2006) Seafloor habitat mapping of the New York Bight incorporating sidescan sonar data. Estuar Coast Shelf Sci 68:221-230

Littell RC, Stroup WW, Freund RJ (2002) SAS for linear models, 4th edn. SAS Institute, Cary, NC

Malatesta RJ, Auster PJ (1999) The importance of habitat features in low-relief continental shelf environments. Oceanol Acta 22:623-626

- Manderson J, Palamara L, Kohut J, Oliver MJ (2011) Ocean observatory data are useful for regional habitat modeling of species with different vertical habitat preferences. Mar Ecol Prog Ser 438:1-17

Moser J, Shepherd GR (2009) Seasonal distribution and movement of black sea bass (Centropristis striata) in the Northwest Atlantic as determined from a markrecaptured experiment. J Northwest Atl Fish Sci 40: $17-28$

Musick JA, Mercer LP (1977) Seasonal distribution of black sea bass, Centropristis striata, in the Mid-Atlantic Bight with comments on the ecology and fisheries of the species. Trans Am Fish Soc 106:12-25

NEFSC (Northeast Fisheries Science Center) (2004) 39th Northeast Regional Stock Assessment Workshop (39th SAW) Assessment Summary Report. US Dept Commerce, Northeast Fish Sci Cent Ref Doc 04-10a, NOAA, Woods Hole, MA

NEFSC (Northeast Fisheries Science Center) (2012) 53rd Northeast Regional Stock Assessment Workshop (53rd SAW) Assessment Summary Report. US Dept Commerce, Northeast Fish Sci Cent Ref Doc 12-05, NOAA, Woods Hole, MA

Nelson DA, Perry D, Baker E (2003) Natural spawning of black sea bass, Centropristis striata, at the NMFS Milford Laboratory and the UMASS Dartmouth laboratory with observations on spawning behavior. J Shellfish Res 22: 297-298

Editorial responsibility: Nicholas Tolimieri, Seattle, Washington, USA
Neufeld MD, Spence CR (2004) Evaluation of a simple decompression procedure to reduce decompression trauma in trap-caught burbot. Trans Am Fish Soc 133: 1260-1263

O'Farrell MR, Yoklavich MM, Love MS (2009) Assessment of habitat and predator effects on dwarf rockfishes (Sebastes spp.) using multi-model inference. Environ Biol Fishes 85:239-250

Parker RO Jr, Chester AJ, Nelson RS (1994) A video transect method for estimating reef fish abundance, composition, and habitat utilization at Gray's Reef National Marine Sanctuary, Georgia. Fish Bull 92:787-799

Pincock DG, Voegeli FW (2002) A quick course in underwater telemetry systems. VEMCO, Halifax, NS

Pollock KH, Winterstein SR, Conroy MJ (1989a) Estimation and analysis of survival distributions for radio tagged animals. Biometrics 45:99-109

> Pollock KH, Winterstein SR, Bunck CM, Davis PD (1989b) Survival analysis in telemetry studies: the staggered entry design. J Wildl Manag 53:7-15

Quinn GP, Keough MJ (2002) Experimental design and data analysis for biologists. Cambridge University Press, New York, NY

> Reebs SG (2002) Plasticity of diel and circadian activity rhythms in fishes. Rev Fish Biol Fish 12:349-371

Roy EM, Quattro JM, Greig TW (2012) Genetic management of black sea bass: influence of biogeographic barriers on population structure. Mar Coast Fish Dynam Manag Ecosys Sci 4:391-402

Schwab WC, Denny JF, Butman B, Danforth WW and others (2000) Seafloor characterization offshore of the New York-New Jersey metropolitan area using sidescansonar. US Geological Survey Open-File Report 00-295. Available at http://pubs.usgs.gov/of/2000/of00-295

Shepherd GR, Idoine JS (1993) Length-based analyses of yield and spawning biomass per recruit for black sea bass Centropristis striata, a protogynous hermaphrodite. Fish Bull 91:328-337

Shepherd GR, Terceiro M (1994) The summer flounder, scup and black sea bass fishery of the Middle Atlantic Bight and Southern New England waters. NOAA Technical Report NMFS 122, US Dept Commerce, Springfield, VA

Steimle FW, Figley W (1996) The importance of artificial reef epifauna to black sea bass diets in the Middle Atlantic Bight. N Am J Fish Manag 16:433-439

Steimle FW, Zetlin C (2000) Reef habitats in the middle Atlantic Bight: abundance, distribution, associated biological communities, and fishery resource use. Mar Fish Rev 62:24-42

Sutherland KR, Beet AR, Solow AR (2010) Re-analysis of a salp population time-series. Mar Ecol Prog Ser 418: $147-150$

Wearmouth VJ, Sims DW (2009) Movement and behavior patterns of the critically endangered common skate Dipturus batis revealed by electronic tagging. J Exp Mar Biol Ecol 380:77-87

Wilk SJ, Morse WW, Stehlik LL (1990) Annual cycles of gonad-somatic indices as indicators of spawning activity for selected species of finfish collected from the New York Bight. Fish Bull 88:775-786

Submitted: October 23, 2012; Accepted: February 4, 2013 Proofs received from author(s): April 17, 2013 